\title{
PENDIDIKAN KARAKTER DALAM ISLAM: PERSPEKTIF FILSAFAT (Character Education In Islam: A Philosophy Perspective)
}

\author{
Felta Felta
}

\begin{abstract}
Abstrak
Character education in Indonesia currently discusses a lot about character education, one of which is at seminars, both local and national seminars. If we are browsing on the internet about character education, there must be a lot of blogs that discuss the theme of character education. Most of the writings have high hopes about the importance of the meaning of character education. There are also those who offer ways to carry out character education both in the school environment, community or in the State (state). All of that should be appreciated as a form of public concern for the urgency of character education at this time.

It does not rule out that all of this must be further questioned, what exactly is the content and process that character education is trying to carry out and achieve. Lots of philosophical questions that need answers, one of which is how to build character in Islam.

Related to character education in Islam, lately people are increasingly aware of the importance of character education or in Islam it is called noble moral education. Part or all of the people agree with this theory. Everyone attaches importance. Even what always appears is mutually reinforcing the statement.
\end{abstract}

Keywords: education, character, Islam, perspective, philosophy 


\section{A. Pendahuluan}

Pendidikan karakter di Indonesia saat ini banyak sekali yang membahas mengenai pendidikan karakter, salah satunya pada acara seminar, baik seminar lokal maupun Nasional. Jika kita browsing di internet mengenai pendidikan karakter, maka pasti banyak sekali blog yang membahas tema pendidikan karakter. Sebagian besar tulisan menaruh harapan besar mengenai pentingnya arti pendidikan karakter. Ada juga yang menawarkan cara melaksanakan pendidikan karakter baik di lingkungan sekolah, masyarakat ataupun di Negara (bernegara). Semua itu patut diapresiasi sebagai wujud kepedulian masyarakat terhadap urgensi pendidikan karakter pada saat ini.

Tidak menutup kemungkinan semua itu masih harus dipertanyakan lebih jauh, apa sesungguhnya isi dan proses yang hendak dijalankan dan dicapai oleh pendidikan karakter. Banyak sekali pertanyaan-pertanyaan filosofis yang membutuhnkan jawaban salah satunya bagaimana pendidikan karakter dalam Islam.

Terkait dengan pendidikan karakter dalam Islam, akhir-akhir ini orang semakin menyadari betapa pentingnya pendidikan karakter atau dalam Islam disebut dengan istilah pendidikan akhlak mulia. Sebagaian ataupun seluruh orang setuju dengan teori tersebut. Semuanya menganggap penting. Bahkan yang selalu muncul adalah sama-sama saling memperkuat pernyataan itu.

Dunia intersubjektif ikut andil dalam menentukan kehidupan anak-anak remaja dalam lingkungan masyarakat. Artinya, tabiat, sifat, dan perilaku anak-anak remaja dipengaruhi oleh budaya dalam lingkungannya. Budaya tersebut termanifestasi dalam mengelola dan memengaruhi pembawaan sifat dan perilaku para remaja. Hal ini sejalan dengan pendapat Ritzer (dalam Susiati, et.al, 2021), dunia intersubjektif menciptakan suatu realitas sosial yang dipaksa oleh struktur budaya dan lingkungan sosial ciptaan leluhur mereka sebelumnya (hal. 35)

Improving the quality of education is one of the most important elements in efforts to improve the quality of human resources, especially in the effectiveness og the teaching and learning process. The effectiveness in the teaching and learning process can be created if the instructor can utilize the learning methods that are suitable to the conditions of the students and the material that will be presented (Susiati, et.al, 2019).

Kecerdasan intelektual tanpa diikuti dengan karakter atau akhlak yang mulia maka tidak akan ada gunanya. Maka dari itu, karakter atau akhlak adalah sesuatu yang sangat mendasar dan saling melengkapi. Masyarakat yang tidak berkarakter atau berakhlak mulia maka disebut sebagai manusia tidak beradab dan tidak memiliki harga atau nilai sama sekali. Oleh karena itu, maka aspek tersebut dipandang sangat penting.

Oleh karena itu, pada diri remaja diperlukan sosialisasi dan internalisasi nilai-nilai semenjak mereka masih kecil. Ritzer (2014) mengatakan bahwa syarat dan fungsi bagi terpeliharanya integritas pola nilai di dalam sistem adalah proses internalisasi dan sosialisasi (hal. 86). Susiati (2019) mengatakan bahwa manusia adalah makhluk sosial yang perkembangan jiwanya tidak ditentukan sejak lahir tetapi dibentuk oleh lingkungannya. Lingkungan manusia itulah yang disebut kebudayaan (hal. 117). 
Karakter atau akhlak mulia itu harus dibangun. Sedangkan membangun akhlak mulia adalah melalui pendidikan, baik pendidikan di rumah (keluarga), di sekolah, maupun di masyarakat. Untuk membentuk karakter atau akhlak mulia memerlukan pendidikan karakter dan pendidikan agama. Maka dari itu dalam pembahasan ini akan dibahas mengenai pendidikan karakter dalam pandangan Islam.

Pendidikan merupakan pilar penting dalam perkembangan kognisi anak. Sejak dimulainya peradaban manusia disitu pulalah pendidikan muncul. Pendidikan adalah suatu runtunan dalam cara pemerolehan ilmu dan penyempurnaan diri yang dilakukan manusia secara terus menerus atau berkelanjutan. Manusia tidak luput dari keterbatasan dan kekurangan sehingga untuk melengkapi keterbatasan dan kekurangan yang dimiliki tersebut, manusia harus berproses, salah satunya melalui pemerolehan ilmu melalui pendidikan. Pendidikan yang diperoleh oleh manusia tidak hanya melalui pendidikan formal tetapi pendidikan awal yang didapatkan oleh manusia adalah melalui lingkungan keluarga dan lingkungan masyarakat (Tuasalamony et.al, 2020).

Peranan orang tua dalam membentuk suatu karakter anak sangatlah penting sebab pertama kali anak menerima sosialisasi dari lembaga keluarga. orang tua merupakan cerminan dari anak sehingga anak akan menjadi apa nantinya bergantung dari cara didikan orang tua terutama karakter khususnya dalam sikap religiusitas anak dalam bermasyarakat. Pendidikan beragama juga sangat penting diberikan kepada anak karena hal tersebut dapat menjadi bekal seorang anak dalam kehidupan bermasyarakat kelak. Peran orang tua dalam memberikan pendidikan religiusitas kepada anak sangat terlihat. Pendidikan religiusitas sangat penting bagi mereka untuk didapatkan oleh anak pada usia dini. Bagi para orang tua, dengan pendidikan agama yang diberikan kepada anak, dapat memberikan pemahaman tentang baik buruk dalam masyarakat sehingga anakanak tersebut kelak tidak terjerumus dalam hal-hal yang bersifat negatif (Buton, et.al, 2020).

Masyarakat menjadi lebih berfikir ilmiah terhadap segala tindakan khususnya dalam bidang pendidikan dan pengajaran terhadap para generasi atau para remaja. Dahulu masyarakat tidak mengutamakan pendidikan karena masyarakat menganggap bahwa berpendidikan tinggi sangat menguras harta. Selain itu, dulu banyak para remaja yang tidak melanjutkan sekolah di perguruan tinggi karena belum adanya Universitas di Kabupaten Buru. Padahal dengan mengenyam pendidikan sampai ke perguruan tinggi, jika selesai akan mengubah aspek kehidupan baik kepada diri sendiri maupun ketika berada di masyarakat (Hatuwe et.al, 2021).

B. Hakikat Pendidikan Karakter dalam Islam

Sebelum kita membahas mengenai pendidikan karakter ada baiknya kita mengetahui apa itu pendidikan dan apa itu karakter. Setelah kita mengetahui makna kedua kata tersebut kita akan dapat memahami apa yang dimaksud dengan pendidikn karakter tersebut.

Kata pendidikan dalam bahasa Yunani dikenal dengan nama paedagoso yang berarti penuntun anak. Dalam bahasa Romawi dikenal dengan aducare artinya membawa 
keluar. Bahasa belanda menyebutkan istilah pendidikan dengan nama opvoeden yang berarti membesarkan atau mendewasakan. Dalam bahasa Inggris disebut dengan istilah aducate/aducating yang berarti to give intellectual training artinya menanamkan moral dan melatih intelektual (http://lib.uin-malang.ac.id/thesis/chapter_ii/10770014sholikah.ps diakses 19 maret 2013 pkl. 21.41).

Sementara dalam pandangan Islam, pendidikan dalam bahasa arab bisa disebut dengan istilah tarbiyah yang berasal dari kata kerja rabba, sedangkan pengajaran dalam bahasa arab disebut dengan $t^{\prime}$ 'lim yang berasal dari kata kerja 'allama. Pendidikan Islam sama dengan Tarbiyah Islamiyah. Kata rabba beserta cabangnya banyak dijumpai dalam al-Quran, misalnya dalam Q.S. al-Isra' [17]: 24 dan Q.S. asy-Syu'ara' [26]: 18, sedangkan kata 'allama antara lain terdapat dalam Q.S. al-Baqarah [2]: 31 dan Q.S. an-Naml [27]: 16. Tarbiyah sering juga disebut $t a^{\prime} d i b$ seperti sabda Nabi SAW.: addabani rabbi fa absana ta'dibi (Tuhanku telah mendidikku, maka aku menyempurnakan pendidikannya) (Moh. Roqib,2009:14).

Pendidikan adalah usaha sadar dan terencana untuk mewujudkan suasana belajar dan proses pembelajaran agar peserta didik secara aktif mengembangkan potensi dirinya untuk memiliki kekuatan spiritual keagamaan, pengendalian diri, kepribadian, kecerdasan, akhlak mulia, serta ketrampilan yang diperlukan dirinya, masyarakat, bangsa dan Negara. (UU SisDikNas, BAB I : pasal 1 ayat 1).

Pendidikan dalam pengertian secara umum dapat diartikan sebagai proses transmisi pengetahuan dari satu orang kepada orang lainnya atau dari satu generasi ke generasi lainnya semua itu dapat berlangsung seumur hidup, selama manusia masih berada di muka bumi ini.

Selain pengertian di atas ada beberapa pengertian mengenai pendidikan sebagai berikut (Hamdani Hamid,2010:23) :

1. Pengertian dalam arti sempit ialah segala pengaruh yang diupayakan sekolah terhadap anak atau remaja yang diserahkan kepadanya, agar mempunyai kemampuan yang sempurna dan kesadaran penuh tentang hubungan-hubungan dan tugas sosial.

2. Pengertian dalam arti agak luas ialah usaha sadar yang dilakukan oleh keluarga, masyarakat dan pemerintah melalui kegiatan bimbingan, pengajaran atau pelatihan yang berlangsung disekolah dan luar sekolah untuk mempersiapkan peserta didik agar dapat memainkan peranan secara tepat dalam berbagai lingkungan hidup.

3. Pengertian dalam arti sangat luas ialah segala pengalaman belajar yang berlangsung dalam segala lingkungan hidup dan sepanjang hidup.

Sementara itu penulis Barat seperti John Dewey sebagaimana dikutip Moh. Haitami Salim dan Erwin Mahrus (2012:9), menyatakan pendidikan adalah proses pembentukan kecakapan fundamental secara intelektual dan emosional ke arah alam sesama manusia.

Dari beberapa pengertian di atas, dapat diambil kesimpulan bahwa pendidikan adalah usaha sadar dan terencana yang dilakuan oleh pendidik kepada perserta didik untuk mewujudkan suasana belajar dan proses pembelajaran agar peserta didik secara aktif mengembangkan potensi dirinya untuk memiliki kekuatan spiritual keagamaan, pengendalian diri, kepribadian, kecerdasan, akhlak mulia, serta 
keterampilan yang diperlukan dirinya, masyarakat, bangsa dan Negara dengan cara pemebelajaran, bimbingan, pelatihan dan semua itu berlangsung seumur hidup.

Dari pengertian di atas, jelas sekali bahwa pendidikan tidak hanya bertitik berat pada kecerdasan intelektual saja melainkan juga pembentukan karakter anak. Pendidikan tidak hanya sekedar proses belajar guna mengejar kecerdasan tetapi juga harus mengembangkan potensi lain yang dimiliki peserta didik dan mendapat perhatian dari pendidik agar dapat berkembang secara optimal. Sementara itu definisi karakter dalamprinsip etimologis, kata karakter (Inggris: character) berasal dari bahasa Yunani (Greek), yaitu charassein yang berarti "to engrave". Kata "to engrave" bisa diterjemahkan mengukir, melukis, memahatkan, atau menggoreskan (Marzuki,tth:4).

Dalam Kamus Besar Bahasa Indonesia (KBBI. 2012), kata "karakter" diartikan dengan tabiat, sifat-sifat kejiwaan, akhlak atau budi pekerti yang membedakan seseorang dengan yang lain dan watak. Dalam pusat bahasa Depdiknas (2008:682) sebagaimana dikutip Marzuki (tth:4), karakter juga bisa berarti huruf, angka, ruang, simbul khusus yang dapat dimunculkan pada layar dengan papan ketik. Orang berkarakter berarti orang yang berkepribadian, berperilaku, bersifat, bertabiat, atau berwatak.

Dengan demikian karakter juga dapat diartikan sebagai kepribadian atau akhalak. Kepribadian merupakan ciri, karakteristik atau sifat khas dalam diri seseorang. Karakter bisa terbentuk melalui lingkungan, misalnya lingkungan keluarga pada masa kecil ataupun bawaan dari lahir. Ada yang berpendapat baik dan buruknya karakter manusia memanglah bawaan dari lahir. Jika jiwa bawaannya baik, maka manusia itu akan berkarakter baik. Tetapi pendapat itu bisa saja salah. Jika pendapat itu benar, maka pendidikan karakter tidak ada gunanya, karena tidak akan mungkin merubah karakter orang.

Sementara itu, ada juga yang berpendapat karakter itu bisa dibentuk dan diupayakan. Dalam pendapat ini mengandung makna bahwa pendidikan karakter sangat berguna untuk merubah manusia menjadi manusia yang berkarakter baik.

Sebenarnya karakter juga bisa diartikan sebagai tabiat, yang bermaknakan perangai atau perbuatan yang selalu dilakukan atau kebiasaan atau bisa diartikan sebagai watak, yaitu sifat batin manusia yang mempengaruhi segenap pikiran dan tingkah laku atau kepribadian.

Orang yang berlaku tidak jujur, kejam atau rakus dikatakan sebagai orang yang berkarakter jelek, sementara orang yang berperilaku jujur dan suka menolong dikatakan sebagai orang yang berkarakter mulia (Amirulloh Syarbini,2012:15). Dalam al-Quran, manusia adalah makhluk dengan berbagai karakter. Dalam kerangka besar manusia mempunyai dua karakter yang saling berlawanan, yaitu karakter baik dan buruk. Sebagaimana firman Allah dalam surat asy-Syam ayat 8-10.

Artinya:

"Maka Allah mengilhamkan kepada jiwa itu (jalan) kefasikan dan ketakwaannya. Sesungguhnya beruntunglah orang yang mensucikan jiwa itu. Dan Sesungguhnya merugilah orang yang mengotorinya". (Q.S. Asy-Syam: 8-10).

Karakter dapat diartikan juga dengan nilai-nilai perilaku manusia yang berhubungan dengan Tuhan Yang Maha Esa, diri sendiri, sesama manusia, lingkungan 
dan kebangsaan yang terwujud dalam pikiran, sikap, perasaan, perkataan dan perbuatan yang berlandaskan norma-norma agama, hukum, tata karma, budaya dan adat istiadat yang berlaku di lingkungannya.

Sedangkan secara terminology, makna karakter dikemukakan oleh Thomas Lickona (1991:51) sebagaimana yang dikutip Marzuki,tth:5), yang mengemukakan bahwa karakter adalah "A reliable inner disposition to respond to situations in a morally good way." Selanjutnya, Lickona menambahkan, "Character so conceived has three interrelated parts: moral knowing, moral feeling and moral behavior". Menurut Lickona, karakter mulia (good character) meliputi pengetahuan tentang kebaikan (moral khowing), lalu menimbulkan komitmen (niat) terhadap kebaikan (moral feeling) dan akhirnya benar-benar melakukan kebaikan (moral behavior). Dengan kata lain, karakter mengacu kepada serangkaian pengetahuan (cognitives), sikap (attitudes) dan motivasi (motivations), serta perilaku (behaviors) dan keterampilan (skills).

Dari beberapa pengertian di atas maka, karakter tersebut sangat identik dengan akhlak, sehingga karakter dapat diartikan sebagai perwujudan dari nilai-nilai perilaku manusia yang universal serta meliputi seluruh aktivitas manusia, baik hubungan antar manusia dengan tuhan (hablumminallah), hubungan manusia dengan manusia (hablumminannas) serta hubungan manusia dengan lingkungannya.

Nilai-nilai tersebut dirumuskan oleh Kemendiknas (2010) sebagaimana yang dikutip oleh Muhammad Kosim (tth.89-90), yaitu ada 18 nilai sebagai beriktu:

1. Religius

Sikap dan perilaku yang patuh dalam melaksanakan ajaran agama yang dianutnya, toleran terhadap pelaksanaan ibadah agama lain, dan hidup rukun dengan pemeluk agama lain.

2. Jujur

Perilaku yang didasarkan pada upaya menjadikan dirinya sebagai orang yang selalu dapat dipercaya dalam perkataan, tindakan, dan pekerjaan.

3. Toleransi

Sikap dan tindakan yang menghargai perbedaan agama, suku, etnis, pendapat, sikap, dan tindakan orang lain yang berbeda dari dirinya.

4. Disiplin

Tindakan yang menunjukkan perilaku tertib dan patuh pada berbagai ketentuan dan peraturan.

5. Kerja Keras

Tindakan yang menunjukkan perilaku tertib dan patuh pada berbagai ketentuan dan peraturan.

6. Kreatif

Berpikir dan melakukan sesuatu untuk menghasilkan cara atau hasil baru dari sesuatu yang telah dimiliki.

7. Mandiri 
Sikap dan perilaku yang tidak mudah tergantung pada orang lain dalam menyelesaikan tugas-tugas.

8. Demokratis

Cara berfikir, bersikap, dan bertindak yang menilai sama hak dan kewajiban dirinya dan orang lain.

9. Rasa Ingin Tahu

Sikap dan tindakan yang selalu berupaya untuk mengetahui lebih mendalam dan meluas dari sesuatu yang dipelajarinya, dilihat, dan didengar.

10. Semangat Kebangsaan

Cara berpikir, bertindak, dan berwawasan yang menempatkan kepentingan bangsa dan negara di atas kepentingan diri dan kelompoknya.

11. Cinta Tanah Air

Cara berpikir, bertindak, dan berwawasan yang menempatkan kepentingan bangsa dan negara di atas kepentingan diri dan kelompoknya.

12. Menghargai Prestasi

Sikap dan tindakan yang mendorong dirinya untuk menghasilkan sesuatu yang berguna bagi masyarakat, dan mengakui, serta menghormati keberhasilan orang lain.

13. Bersahabat/Komunikatif

Sikap dan tindakan yang mendorong dirinya untuk menghasilkan sesuatu yang berguna bagi masyarakat, dan mengakui, serta menghormati keberhasilan orang lain.

14. Cinta Damai

Sikap dan tindakan yang mendorong dirinya untuk menghasilkan sesuatu yang berguna bagi masyarakat, dan mengakui, serta menghormati keberhasilan orang lain.

15. Gemar Membaca

Kebiasaan menyediakan waktu untuk membaca berbagai bacaan yang memberikan kebajikan bagi dirinya.

16. Peduli Lingkungan

Sikap dan tindakan yang selalu berupaya mencegah kerusakan pada lingkungan alam di sekitarnya, dan mengembangkan upaya-upaya untuk memperbaiki kerusakan alam yang sudah terjadi.

17. Peduli Sosial

Sikap dan tindakan yang selalu ingin memberi bantuan pada orang lain dan masyarakat yang membutuhkan.

18. Tanggung Jawab

Sikap dan perilaku seseorang untuk melaksanakan tugas dan kewajibannya, yang seharusnya dia lakukan, terhadap diri sendiri, masyarakat, lingkungan (alam, sosial dan budaya), negara dan Tuhan Yang Maha Esa.

Seperti yang telah dijelaskan di atas, bahwa karakter identik dengan akhlak. Maka dalam perspektif Islam, karakter atau akhlak mulia merupakan suatu hasil yang 
dihasilkan dari proses penerapan syariat (Ibadan dan muamalah) yang dilandasi oleh fondasi aqidah yang kokoh dan bersandar pada al-Quran dan as-Sunah (hadis).

Dari konsep karakter dan pendidikan maka muncul yang namanya pendidikan karakter (character education). Terminology pendidikan karakter mulai dikenalkan sejak tahun 1990-an. Thomas Lickona dianggap sebagai pengusungnya, terutama ketika bukunya yang berjudul The Return of Character Education kemudian disusul bukunya Educating for Character: How Our School Can Teach Respect and Responsibility (1991). Melalui buku-buku itu, ia menyadarkan dunia Barat akan pentingya pendidikan karakter. Sedangkan di Idonesia sendiri, istilah pendidikan karakter mulai diperkenalkan sekitar tahun 2005-an. Hal itu secara implisit ditegaskan dalam Rencana Pembanguna Jangka Panjang Nasional (RPJPN) tahun 2005-2015, di mana pendidikan karakter ditempatkan sebagai landasan untuk mewujudkan visi pembangunan nasional, yaitu "mewujudkan masyarakat berakhlak mulia, bermoral, beretika, berbudaya dan beradab berdasarkan falsafah pancasila"(Amirulloh Syarbini,2012:16).

Pada penjelasan di atas disinggung masalah pendidikan karater yang identik dengan akhlak. Maka kita perlu tahu apa hubungan pendidikan karakter dengan akhlak secara lebih dalam.

Seperti yang telah dijelaskan di atas, pendidikan akhlak dan pendidikan karakter adalah sama, yaitu sama-sama pembentukan karakter. Perbedaannya adalah jika pendidikan akhlak terkesan ketimur-timuran dan Islami, sedangkan pendidikan karakter terkesan kebarat-baratan dan sekuler[1], semua itu bukanlah alasan untuk diperdebatkan dan dipertentangkan. Pada kenyataannya keduanya memiliki ruang untuk saling mengisi. Bahkan Lickona sebagai Bapak Pendidikan Karakter di Amerika justru mengisyaratkan keterkaitan erat antar karakter dan spiritual (Zubaedi,2012:65). Dengan demikian, bila sejauh ini pendidikan karakter telah berhasil dirumuskan oleh para penggiatnya sampai pada tahapan yang sangat operasional yang meliputi metode, strategi dan teknik, sedangkan pendidikan akhlak syarat dengan informasi kriteria ideal dan sumber karakter baik, maka dari itu jika keduanya dipadukan akan sempurna dalam pembentukan karakter manusia. Hal ini sekaligus dapat menjadi nilai plus bahwa karakter meliki ikatan yang kuat dengan nilai-nilai spiritualitas dan agama.

Menurut terminology Islam, pengertian karakter ,memiliki kedekatan pengertian dengan pengertian akhlak (Zubaedi,2012:65). Menurut etimologi, kata akhlak berasal dari bahasa Arab (اخلاق), bentuk jamak dari mufradnya khuluq (خلق), yang berarti “budi pekerti". Sinonimnya adalah etika dan moral. Etika berasal dari bahasa latin, etos yang berarti kebiasaan. Moral juga berasal dari bahasa latin juga, mores yang berarti kebiasaannya (Zubaedi,2012:65).

Dalam kalimat khuluq mengandung segi-segi persesuaian dengan perkataan khalakun (خلق) yang berarti kejadian, serta erat hubungannya khalik (خلق) yang berarti penciptaan dan makhluk (مخلوق) yang berarti diciptakan. (Zubaedi.2012: 65-66) bahwa".

Menurut Abd. Hamid sebagaimana dikutip Zubaedi (2012:66) menyatakan

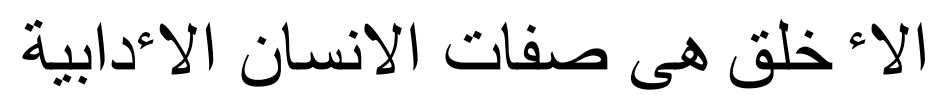


Artinya:

"Akhlak ialah segala sifat manusia yang terdidik".

Memahami pernyataan tersebut dapat dimengerti bahwa sifat atau potensi yang dibawa manusia sejak lahir, maksudnya potensi ini sangat tergantung bagaimana cara pembinaan dan pembentukannya. Apabila pengaruhnya positif, maka sama seperti pendidikan karakter, pendidikan akhlak juga outputnya adalah akhlak mulia dan sebaliknya apabila pembinaannya negatif, yang terbentuk adalah akhlak mazmuniah[2].

Maka dari itu al-Ghazali mendefinisikan akhlak sebagai berikut:

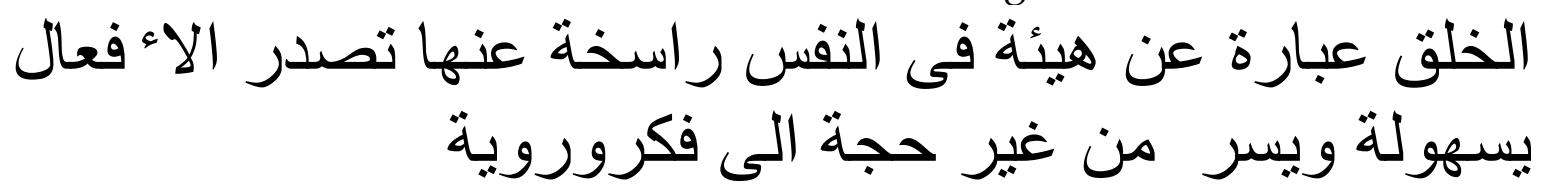

Artinya:

"Akhlaq adalah suatu perangai (watak/tabiat) yang menetap dalam jiwa seseorang dan merupakan sumber timbulnya perbuatan-perbuatan tertentu dari dirinya secara mudah dan ringan tanpa dipikirkan atau direncanakan sebelumnya". (Zubaedi.2012: 67)

Dari beberapa pengertian pendidikan dan karakter di atas maka dapat diambil kesimpulan, pendidikan karakter adalah usaha sadar yang dilakukan pendidik kepada peserta didik untuk membentuk kepribadian peserta didik yang mengajarkan dan membentuk moral, etika, dan rasa berbudaya yang baik serta berakhlak mulia yang menumbuhkan kemampuan peserta didik untuk memberikan keputusan baik dan buruk serta mewujudkan kebaikan itu dalam kehidupan sehari-hari dengan cara melakukan pendidikan, pengajaran, bimbingan dan pelatihan.

Dari uraian di atas dapat disimpulkan bahwa yang dimaksud pendidikan karakter adalah bukan jenis mata pelajaran seperti Pendidikan Agama Islam (PAI), Pendidikan Moral Pancasila (PMP) atau lainnya, tetapi proses internalisasi atau penanaman nilainilai positif kepada peserta didik agar mereka memiliki karakter yang baik (good character) sesuai dengan nilai-nilai yang dirujuk, baik dari agama, budaya, maupun falsafah Negara (Amirulloh Syarbini,2012:18).

Jadi, pendidikan karakter menurut pandangan Islam adalah usaha sadar yang dilakukan pendidik kepada peserta didik untuk membentuk kepribadian peserta didik yang mengajarkan dan membentuk moral, etika, dan rasa berbudaya yang baik serta berakhlak mulia yang menumbuhkan kemampuan peserta didik untuk memberikan keputusan baik dan buruk serta mewujudkan kebaikan itu dalam kehidupan sehari-hari dengan cara melakukan pendidikan, pengajaran, bimbingan dan pelatihan yang berpedoman pada al-Quran dan as-Sunah.

\section{Dasar-dasar Pendidikan Karakter dalam Islam}

Seperti dijelaskan di atas bahwa karakter identik dengan akhlak. Dalam perspektif Islam, karakter atau akhlak mulia merupakan buah yang dihasilkan dari proses penerapan syariah (ibadah dan muamalah) yang dilandasi oleh fondasi aqidah yang kokoh. Ibarat bangunan, karakter atau akhlak merupakan kesempurnaan dari bangunan tersebut setelah fondasi dan bangunannya kuat (Marzuki.tth:5). 
Tidak mungkin karakter atau akhlak mulia akan terwujud pada diri seseorang apabila ia tidak memiliki aqidah dan syariah yang benar. Seorang Muslim yang memiliki aqidah atau iman yang benar pasti akan terwujud pada sikap dan perilaku dalam kehidupan sehari-hari yang didasari oleh imannya. Sebagai contoh, orang yang memiliki iman yang baik dan benar kepada Allah SWT ia akan selalu mentaati dan melaksanakan seluruh perintah Allah SWT dan menjauhi seluruh larangan-larangan-Nya. Maka dari itu, ia akan selalu berbuat yang baik dan menjauhi hal-hal yang dilarang (buruk).

Iman bukan saja hanya kepada Allah SWT tetapi juga kepada malaikat, kitab, Rasul dan seterusnya akan menjadikan sikap dan perilakunya terarah dan terkendali, sehingga akan mewujudkan akhlak atau karakter mulia. Hal yang sama juga terjadi dalam hal pelaksanaan syariah. Semua ketentuan syariah Islam bermuara pada terwujudnya akhlak atau karakter mulia. Seorang yang melaksanakan shalat yang sesuai dengan ketentuan yang berlaku. Misalnya, pasti dia akan terhindar dan tidak akan melakukan perbuatan yang keji dan munkar serta ia akan selalu melakukan perbuatan yang baik dan terpuji. Seperti dalam firman Allah SWT:

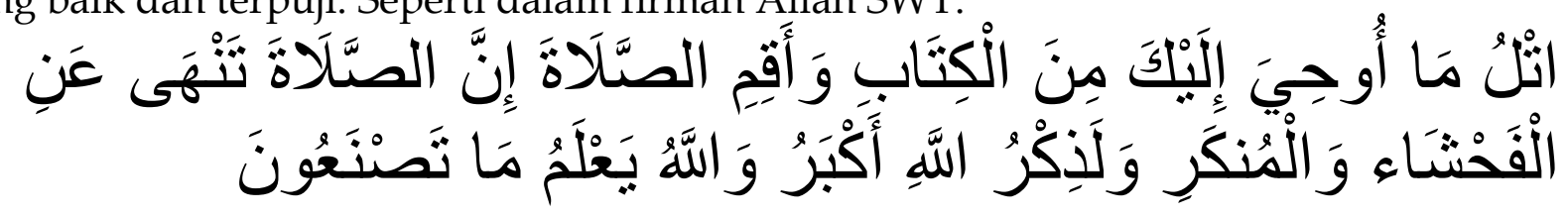

Artinya:

"Bacalah Kitab (al-Quran) yang telah diwahyukan kepadamu (Muhammad) dan laksanakanlah shalat. Sesungguhnya shalat itu mencegah dari (perbuatan) keji dan mungkar. Dan (ketahuilah) mengingat Allah (shalat) itu lebih besar (keutamaannya dari ibadah yang lain). Allah Mengetahui apa yang kamu kerjakan". (Q.S. al-Ankabut: 45).

Ketentuan syariat seperti shalat tersebut bukan saja hanya pada shalat tetapi juga pada syariat-syariat lain seperti zakat, puasa dan lain sebagainya.

Dalam pendidikan karakter yang terpenting bukan hanya sebatas mengkaji dan mendalami konsep akhlak, tetapi sarana dan proses untuk mencapainya juga sangat penting sehingga seseorang dapat bersikap dan berperilaku mulia seperti yang dipesankan oleh Nabi SAW. Dengan konsep akhlak dan proses tersebut akan mengarahkan pada tingkah laku sehari-hari, sehingga sesorang dapat memahami yang dilakukannya baik dan benar ataupun buruk dan salah, termasuk karakter mulia (akhlaq mahmudah) atau karakter tercela (akhlaq madzmumah).

Baik dan buruk karakter manusia sangat tergantung pada tata nilai yang dijadikan pijakannya. Abul A'la al-Maududi sebagaimana dikuti Marzuki (tth:6) membagi sistem moralitas menjadi dua. Pertama, sistem moral yang berdasar kepada kepercayaan kepada Tuhan dan kehidupan setelah mati. Kedua, sistem moral yang tidak mempercayai Tuhan dan timbul dari sumber-sumber sekuler. Sistem moralitas yang pertama sering juga disebut dengan moral agama, sedang sistem moralitas yang kedua sering disebut moral sekuler.

Sistem moralitas yang pertama (moral agama) dapat ditemukan pada sistem moralitas Islam (akhlak Islam). Hal ini karena Islam menghendaki dikembangkannya al- 
Akhlaq al-Karimah yang pola perilakunya dilandasi dan untuk mewujudkan nilai Iman, Islam dan Ihsan.

Sedangkan sistem moralitas yang kedua menurut (moral sekuler) menurut Faisal Ismail (1998: 181) adalah sistem yang dibuat atau sebagai hasil pemikiran manusia (secular moral philosophies) dengan mendasarkan pada sumber-sumber sekuler, baik murni dari hukum yang ada dalam kehidupan, intuisi manusia, pengalaman, maupun karakter manusia) (Marzuki.tth:7).

Dalam al-Quran ditemukan banyak sekali pokok-pokok keutamaan karakter atau akhlak yang dapat digunakan untuk membedakan perilaku seorang Muslim, seperti perintah berbuat kebaikan (ihsan) dan kebajikan (al-birr), menepati janji (al-wafa), sabar, jujur, takut pada Allah Swt., bersedekah di jalan Allah, berbuat adil, dan pemaaf (QS. alQashash [28]: 77; QS. al-Baqarah [2]: 177; QS. al-Muminun (23): 1-11; QS. al-Nur [24]: 37; QS. al-Furqan [25]: 35-37; QS. al-Fath [48]: 39; dan QS. Ali 'Imran [3]: 134). Ayat-ayat ini merupakan ketentuan yang mewajibkan pada setiap Muslim melaksanakan nilai karakter mulia dalam berbagai aktivitasnya (Marzuki.tth:8).

Keharusan menjunjung tinggi karakter mulia (akhlaq karimah) lebih dipertegas lagi oleh Nabi Saw. dengan pernyataan yang menghubungkan akhlak dengan kualitas kemauan, bobot amal dan jaminan masuk surga. Sabda Nabi Saw. yang diriwayatkan oleh Abdullah Ibn Amr: "Sebaik-baik kamu adalah yang paling baik akhlaknya ..." (HR. al-Tirmidzi). Dalam hadis yang lain Nabi Saw. bersabda: "Sesungguhnya orang yang paling cinta kepadaku di antara kamu sekalian dan paling dekat tempat duduknya denganku di hari kiamat adalah yang terbaik akhlaknya di antara kamu sekalian ..." (HR. al-Tirmidzi). Dijelaskan juga dalam hadis yang lain, ketika Nabi Saw ditanya: "Apa yang terbanyak membawa orang masuk ke dalam surga?" Nabi Saw. menjawab: "Takwa kepada Allah dan berakhlak baik." (HR. al-Tirmidzi) (Marzuki.tth:8).

Menurut Ainain sebagimana dikuti Marzuki (tth.8), dalil-dalil di atas menunjukkan bahwa karakter dalam perspektif Islam bukan hanya hasil pemikiran dan tidak berarti lepas dari realitas hidup, melainkan merupakan persoalan yang terkait dengan akal, ruh, hati, jiwa, realitas dan tujuan yang digariskan oleh akhlaq qur'aniah. Dengan demikian, karakter mulia merupakan sistem perilaku yang diwajibkan dalam agama Islam melalui nash al-Quran dan hadis.

Namun demikian, kewajiban yang dibebankan kepada manusia bukanlah kewajiban yang tanpa makna dan keluar dari dasar fungsi penciptaan manusia. AlQuran telah menjelaskan masalah kehidupan dengan penjelasan yang realistis, luas dan juga telah menetapkan pandangan yang luas pada kebaikan manusia dan zatnya. Makna penjelasan itu bertujuan agar manusia terpelihara kemanusiaannya dengan senantiasa dididik akhlaknya, diperlakukan dengan pembinaan yang baik bagi hidupnya, serta dikembangkan perasaan kemanusiaan dan sumber kehalusan budinya. Dengan demikian, menurut al-Bahi sebagaiman dikutip Marzuki (tth.9), karakter telah melekat dalam diri manusia secara fitriah.

Dengan kemampuan fitriah ini ternyata manusia mampu membedakan bata s kebaikan dan keburukan, dan mampu membedakan mana yang tidak bermanfaat dan mana yang tidak berbahaya. Sebenarnya pembawaan fitrah manusia ini tidak serta merta 
menjadikan karakter manusia bisa terjaga dan berkembang sesuai dengan fitrah tersebut. Fakta membuktikan bahwa pengalaman yang dihadapi masing-masing orang menjadi faktor yang sangat dominan dalam pembentukan dan pengamalan karakternya. Disinilah pendidikan karakter mempunyai peran yang penting dan strategis bagi manusia dalam rangka melalukan proses internalisasi dan pengamalan nilai-nilai karakter mulia di masyarakat.

D. Tujuan Pendidikan Karakter

Tujuan dari pendidikan karakter menurut Islam adalah menjadikan manusia yang berakhlak mulia. Dalam hal ini yang menjadi tolok ukur adalah akhlak Nabi Muhammad SAW dan yang menjadi dasar pembentukan karakter adalah al-Quran. Tetapi kita kita harus menyadari tidak ada manusia yang menyamai akhlaknya dengan Nabi Muhammad SAW.

Sebagaimana seperti dalam hadis riwayat Muttafaq 'alaih, berikut:

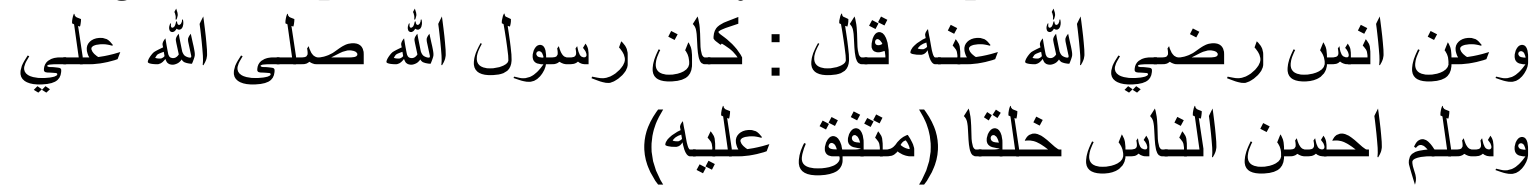

Artinya:

"Anas ra. Berkata, "Rasulullah Saw. adalah orang yang paling baik budi pekertinya"". (Muttafaq 'alaih). (Mustofa Said al-Khim, dkk.2012: 695)

Dari hadis tersebut bahwa, sangat jelas akhlak Rasulullah adalah bukti bahwa akhlak beliau sangat sempurna. Dalam hadis ini juga memperkuat pendapat Bambang Q-Anees (2009:6) bahwa Nabi Muhammad Saw. adalah al-Quran berjalan, karena dalam diri Rasulullah terdapat al-Quran tersebut dan beliau tidak pernah sekalipun melakukan perbuatan yang menyimpang dan melenceng dari akhlak mulia.

Al-Quran adalah petunjuk bagi umat Islam. Seperti yang telah disinggung di atas bila kita hendak mengarahkan pendidikan kita dan menumbuhkan karakter yang kuat pada anak didik, kita harus mencontoh karakter Nabi Muhammad SAW yang memiliki karakter yang sempurna.

Firman Allah SWT yang artinya:

"Dan Sesungguhnya kamu benar-benar berbudi pekerti yang agung". (Q.S. al-Qalam : 4)

Dalam pendidikan karakter yang berorientasi pada akhlak mulia kita wajib untuk berbuat baik dan saling membantu serta dilatih untuk selalu sabar, menahan amarah dan memaafkan kesalahan orang lain sebagaimana firman Allah SWT yang artinya:

"..... dan orang-orang yang menahan amarahnya dan mema'afkan (kesalahan) orang. Allah menyukai orang-orang yang berbuat kebajikan". (Q.S. al-Imran: 134)

Dari uraian di atas maka tujuan pendidikan karakter menurut Islam adalah membentuk pribadi yang berakhlak mulia, karena Akhlak mulia adalah pangkal kebaikan. Orang yang berakhlak mulia akan segera melakukan kebaikan dan meninggalkan keburukan.

E. Urgensi Pendidikan Karakter dalam Islam 
Di tengah peradaban zaman modernisasi yang serba instan dan semakin populer, kaum Islam sekarang lebih memfokuskan diri untuk mendapatkan kesenangan duniawi dibanding mengedepankan nilai agama sebagai kekuatan iman untuk mendapat rakhmat Allah SWT.

Tidak jarang sebagaimana kita ketahui kehidupan generasi muda muslim dimasa sekarang menunjukan seakan-akan akhlak itu tak penting. Walaupun dari segi sarana pendidikan, media cetak dan elektronik, busana, masjid, kuantitas ahli agama bahkan kegiatan dakwah sekalipun yang semakin maju dan berkembang, justru perkembangan itu sebagian besar dipengaruhi oleh modernisasi Ilmu Pengetahuan dan Teknologi (IPTEK) ala Barat.

Sering kita jumpai, corak budaya remaja Islam masa kini, walaupun banyak remaja muslimah yang berbusana panjang tertutup jilbab namun model busana yang dicapai tidak semata-mata diniatkan untuk menutup aurat malah mereka hanya mengikuti trend fasion yang aneh-aneh agar bertujuan terlihat menarik, gaul dan exis bagi orang lain khususnya lawan jenis.

Karakter ini sudah sangatlah parah sebagaimana melanggar perintah Allah SWT. dalam firmannya yang artinya:

"Katakanlah kepada wanita yang beriman: "Hendaklah mereka menahan pandangannya, dan kemaluannya, dan janganlah mereka Menampakkan perhiasannya, kecuali yang (biasa) nampak dari padanya. dan hendaklah mereka menutupkan kain kudung kedadanya, dan janganlah Menampakkan perhiasannya kecuali kepada suami mereka, atau ayah mereka, atau ayah suami mereka, atau putera-putera mereka, atau putera-putera suami mereka, atau saudara-saudara lakilaki mereka, atau putera-putera saudara lelaki mereka, atau putera-putera saudara perempuan mereka, atau wanita-wanita Islam, atau budak-budak yang mereka miliki, atau pelayan-pelayan laki-laki yang tidak mempunyai keinginan (terhadap wanita) atau anak-anak yang belum mengerti tentang aurat wanita. dan janganlah mereka memukulkan kakinyua agar diketahui perhiasan yang mereka sembunyikan. dan bertaubatlah kamu sekalian kepada Allah, Hai orang-orang yang beriman supaya kamu beruntung". (Q.S An-Nur ayat 31).

Kerusakan lain pada remaja misalnya mengenai pergaulan bebas, penggunaan narkoba, tindak kriminal dan lain-lain. pengaruh lingkungan dari pergaulan teman sepermainan maupun ketidakharmonisan dalam keluarga sangat berefek negatif bagi kepribadian remaja muslim. Apalagi anak yang diusianya mulai dewasa ini biasanya suka mencoba hal yang baru dan populer di komunitas lingkungannya. Faktanya dalam kehidupan sekarang banyak orang menganggap saat ini adalah zaman gila-gilaan sehingga jika tidak ikut gila tidak kebagian.

Dalam upaya memperbaiki masalah tersebut, keluarga adalah peran utama dalam membentuk generasi muslim yang berakhlak mulia. Sebagai orang tua harus mampu mendidik anaknya agar lebih baik dan tidak terjerumus dalam hal-hal yang negatif untuk membentuk pendidikan yang berkarakter. Selain peran orang tua, sekolah juga sebagai sarana untuk mendidik siswa-siswanya agar mempunyai pendidikan yang berkarakter. Sekolah merupakan wadah yang sangat efektif untuk membentuk siswa yang berbudi pekerti dan berkarakter tinggi. 
Masalah selanjutnya adalah lingkungan pergaulan. Seseorang dapat baik jika di dalam lingkungannya dia bergaul dengan orang-orang yang baik. Satu orang yang mempunyai akhlak baik berada di dalam seratus orang yang tidak baik dia akan menjadi tidak baik dan sebaliknya, jika ada satu orang yang bermoral buruk berada di antara orang-orang yang baik dia akan menjadi baik.

Dalam upaya ini keluarga harus mampu mencari lembaga pendidikan yang kiranya dapat menunjang anak untuk bisa mendapat ilmu umum sekaligus mengasah agamanya. Contohnya seperti menyekolahkan anak disekolah-sekolah umum tetapi juga mengikut sertakan dalam kegiatan TPQ, sekolah diniah atau di masjid terdekat atau sekaligus memasukan anak ke pesantren yang memiliki sarana sekolah.

Banyak orang beranggapan bahwa pesantren memang sarana yang baik untuk mendidik ilmu agama setiap insan, namun mereka menilai kehidupan pesantren itu kuno, jorok, makanannya tak bergizi, gaptek dan prestasinya kurang bersaing secara global. Anggapan itu justru keliru pesantren sesungguhnya menurut (Soegarda Poerbakawatja) yang dikutip oleh Haidar Putra Daulay mengatakan pesantren berasal dari kata santri yaitu seseorang yg belajar agama Islam sehingga dengan demikian pesantren mempunyai arti tempat orang berkumpul untuk belajar agama Islam. Dari kesederhanaan hidup pesantren itulah yang menjadikan karakter seseorang menjadi lebih bersosialisasi prihatin, bekerja keras, dalam menuntut ilmu dan terhindar dari pengaruh modernisasi luar. (http:// sagotra.blogspot.com/2012/09/pentingnyapendidikan-karakter-dalam_1.html diakses 24 Maret 2013 pukul 20.46).

Seiring perkembangan zaman, budaya pesantren masa kini juga mengalami perkembangan lebih modern, banyak pesantren sekarang yang dilengkapi dengan fasilitas sekolah baik dari tingkat TK/RA, SD/MI, SMP/MTs, SMA/MA bahkan ada juga yang sudah memiliki perguruan tinggi. Teknik pembelajarannya pun mulai mengacu seperti sekolah umum. Jadi jangan heran santri-santri sekarang tidak lagi dianggap lemah dalam era globalisasi. Namun mereka akan lebih memiliki wawasan luas, bisa menguasai ilmu umum sekaligus memperbaiki karakter menjadi lebih saleh dan shalehah.

Dari beberapa peristiwa tersebut dapat dicermati, bahwa peran pendidikan haruslah lebih mengutamakan nilai karakter daripada prestasi tinggi. Bukan berarti prestasi tidak penting tatapi jika berprestasi tetapi tidak memiliki karakter yang bagus maka tidak ada gunanya dan dapat merusak diri sendiri bahkan keluarga, masyarakat dan bangsa.

Dari beberapa masalah di atas maka sangat jelas urgensi atau pentingnya pendidikan karakter pada saat ini karena karakter akan menunjukkan siapa diri kita sebenarnya, karater akan menentukan bagaimana seseorang membuat keputusan, karakter menentukan sikap, perkataan dan perbuatan sesorang, orang yang memiliki karakter baik, maka perkataan dan perbuatannya juga pasti akan baik, sehingga semua itu akan menjadi identitas yang menyatu dan mempersonaliasasi terhadap dirinya, sehingga mudah membedakan dengan identitas lainnya.

F. Implementasi Pendidikan Karakter di Lembaga Pendidikan Islam 
Ki Hajar Dewantara sebagaimana dikutip Amirullah Syarbini (2012:29), membagi lingkungan pendidikan menjadi tiga yang disebut sebagai tri pusat pendidikan, yaitu sekolah/madrasah, keluarga dan masyarakat.

Pada pembahasan kali ini penulis hanya membahas mengenai penerapan pendidikan karakter di lembaga pendidikan Islam.

Lembaga bukanlah ruang hampa makna. Bagi pendidikan karakter keseluruhan lembaga (fisik dan orang-orangnya) haruslah menjadi sumber teladan. Semua pihak yang terlibat di dalam lembaga pendidikan (bahkan pedagang) harus menampilkan diri sebagai teladan pelaksanaan nilai-nilai, juga harus memberikan dorongan bagi seluruh proyek riyadhah (Bambang Q-Anees dan Adang Hambali,2009:129).

Secara sadar atau pun tidak, banyak sekali lembaga pendidikan yang mencoba menerapkan pendidikan karakter pada peserta didiknya. Mengapa demikian, karena masih banyak lembaga atau sekolah-sekolah yang lebih menekannkan hasil belajar saja, bukan bagaimana mendidik peserta didiknya menjadi manusia yang berilmau sekaligus mempunyai karakter atau akhlak yang mulia. Pada dasarnya baik lembaga pendidikan umum atau lembaga pendidikan Islam dalam melaksankan pendidikan karakter kurang lebih sama hanya saja yaitu secara khusus terpusat dengan mata pelajaran PKN dan Pendidikan Agama Islam dan secara umum para guru menyisipkan pendidikan karakter pada mata pelajaran lainnya dengan cara waktu penyamapaian materi baik secara langsung ataupun tidak langsung agar membentuk karakter peserta didik.

Jika pada lemabaga pendidikan formal yang tidak berbasiskan Islam seperti sekolah (SD, SMP dan SMA) pendidikan karakternya melalui mata pelajaran PKN dan PAI, dalam lembaga pendidikan Islam (MI, MTs dan MA) menggunakan mata pelajaran PKN dan PAI yang dipecah-pecah lagi kedalam beberapa mata pelajaran seperti akidah \& akhlak, al-Quran Hadis, dan sebagainya. Jadi dalam pendidikan Islam ini, pendidikan karakternya lebih dominan barbasiskan Agama.

Sebenarnya bukan hanya itu, banyak hal yang dapat dilakukan untuk merealisasikan pendidikan karakter di madrasah. Konsep karakter tidak cukup dijadikan sebagai suatu poin dalam silabus dan rencana pelaksanaan pembelajaran di madrasah, namun harus lebih dari itu. Madrasah harus menjadikan pendidikan karakter sebagai sebuah tatanan nilai yang berkembang dengan baik di madrasah yang diwujudkan dalam contoh dan seruan nyata yang dipertontonkan oleh tenaga pendidik dan kependidikan di madrasah dalam keseharian kegiatan di madrasah. Contohya, extrakulikuler seperti rohis, pramuka dan lain-lain atau pemberian tugas seperti di bulan ramadhan pembagian buku tugas ramadhan untuk meresume pengajian, aktif atau tidaknya shalat taraweh dan sebagainya.

Selanjutnya, pendidikan karakter di pesantren. Telah kita ketahui bahwa pesantren adalah lembaga pendidikan tertua di negeri ini. Ia telah melahirkan tokohtokoh bangsa yang santun, arif dan berkarakter. Cara dalam pesantren menumbuhkan karakter peserta didiknya (santrinya) dengan menekankan pendidikan dan penyempurnaan akhlak. Para santri terus diawasi dan tidak bisa melakukan hal-hal yang menyimpang dalam koridor agama, sehingga para santrinya memiliki akhalak yang baik. 
Kegiatan-kegiatan di pesantren yang dapat menumbuhkan karakter yang baik contohnya seperti, penghafalan al-Quran, hadis, kitab-kitab, pelatihan dibidang kesenian seperti, nasyid, rebbana, tilawah dan sebagainya.

Namun belakangan nama pesantren tercoreng karena peristiwa beberapa oknum yang terlibat dalam gerakan terorisme. Oleh karena itu, sudah saatnya peran dan fungsi pesantren/surau/dayah dioptimalkan kembali sebagai kawah candradimuka pendidikan Islam di Indonesia. Juga sebagai benteng pembangunan akhlak bagi generasi bangsa.

Di sisi lain ada juga pendidikan karakter yang dilakukan di masjid-masjid. Masjid sebagai alternative bagi seseorang yang tidak memiliki biaya untuk memasuki sekolah, madrasah ataupun pesantren untuk menumbuhkan karakter yang baik atau akhlak mulia. Banyak dikalangan ulama yang memberikan ilmu dan bimbingan secara cumacuma demi tercapainya atau terwujudnya karakter dan akhlak mulia bagi seluruh umat manusia.

Biasanya dalam pelaksanaan pendidikan karakter di masjid-masjid, menggunakan metode ta'lim, pengajian dan acara-acara peringatan hari-hari besar Islam. selain itu juga, masjid digunakan sebagai tempat Taman Pendidikan Al-Quran (TPA) yang tidak lain dan tidak bukan tujuanya untuk membentuk karakter perserta didiknya.

G. Penutup

Pendidikan karakter terdiri dari dua kata yaitu pendidikan dan karakter. Arti dari pendidikan karakter menurut Islam adalah usaha sadar yang dilakukan pendidik kepada peserta didik untuk membentuk kepribadian peserta didik yang mengajarkan dan membentuk moral, etika, dan rasa berbudaya yang baik serta berakhlak mulia yang menumbuhkan kemampuan peserta didik untuk memberikan keputusan baik dan buruk serta mewujudkan kebaikan itu dalam kehidupan sehari-hari dengan cara melakukan pendidikan, pengajaran, bimbingan dan pelatihan yang berpedoman pada al-Quran dan as-Sunah.

Yang menjadi dasar pendidikan karakter dalam Islam adalah al-Quran dan Hadis serta akhlak Rasulullah SAW.

Pendidikan karakter sangat penting pada saat ini karena karakter akan menunjukkan siapa diri kita sebenarnya, karater akan menentukan bagaimana seseorang membuat keputusan, karakter menentukan sikap, perkataan dan perbuatan sesorang, orang yang memiliki karakter baik, maka perkataan dan perbuatannya juga pasti akan baik, sehingga semua itu akan menjadi identitas yang menyatu dan mempersonaliasasi terhadap dirinya, sehingga mudah membedakan dengan identitas lainnya.

Tujuan pendidikan kararkter adalah untuk membentuk pribadi yang berakhlak mulia, karena Akhlak mulia adalah pangkal kebaikan. Orang yang berakhlak mulia akan segera meninggalkan kebaikan dan meninggalkan keburukan.

Implementasi pendidikan karakter dalam lembaga pendidikan Islam sangat beragam tergantung kebijakan lembaga pendidikan tersebut. 


\section{DAFTAR PUSTAKA}

Anggota IKAPI. 2010. Undang-Undang SISDIKNAS. Bandung: Fokusmedia. Hamid, Hamdani. 2010. Perbandingan Filsafat Pendidikan. Bandung: SEGA ARSY

Iye, R., \& Susiati, S. (2018). NILAI EDUKATIF DALAM NOVEL SEBAIT CINTA DI BAWAH LANGIT KAIRO KARYA MAHMUD JAUHARI ALI (Educative Values in Sebait Cinta di Bawah Langit Kairo by Mahmud Jauhari Ali). Sirok Bastra, 6(2), 185-191.

Ritzer, G. (2014). Teori Sosiologi Modern. Terjemahan. Jakarta: Kencana Prenadamedia Group.

Susiati, S., Masniati, A., Tuasalamony, K., Hatuwe, R. S. M., Tahir, S. Z. B., Tenriawali, A. Y., \& Marasabessy, R. N. (2020). MEMBANGUN KETAHANAN RELEGIUS ANAK MELALUI ACTIVE PARENTAL INVOLVEMENT. Jurnal Islam Nusantara, 4(1), 111-125.

Susiati, \& Taufik. (2019). Nilai Pembentuk Karakter Masyarakat Wakatobi Melalui Kabhanti Wa Leja. Jurnal Totobuang, 7(1), 117-137.

Susiati, S., Iye, R., \& Suherman, L. O. A. (2019). Hot Potatoes Multimedia Applications in Evaluation of Indonesian Learning In SMP Students in Buru District. ELS Journal on Interdisciplinary Studies in Humanities, 2(4), 556-570.

Susiati, S., Masniati, A., \& Iye, R. (2021). Kearifan Lokal Dalam Perilaku Sosial Remaja Di Desa Waimiting Kabupaten Buru. Sang Pencerah: Jurnal Ilmiah Universitas Muhammadiyah Buton, 7(1), 8-23.

Susiati, S., Tenriawali, A. Y., Nursin, N., Nacikit, J., \& Mukadar, S. (2020). NILAI EDUKASI DALAM NOVEL PARTIKEL KARYA DEWI LESTARI:(The Value of Education in Particle Novels by Dewi Lestari). Uniqbu Journal of Social Sciences, 1(3), 176-183.

Susiati, S. (2020). Nilai Budaya Suku Bajo Sampela Dalam Film The Mirror Never Lies Karya Kamila Andini.

Susiati, S., Tenriawali, A. Y., Nursin, N., Nacikit, J., \& Mukadar, S. (2020). NILAI EDUKASI DALAM NOVEL PARTIKEL KARYA DEWI LESTARI:(The Value of Education in Particle Novels by Dewi Lestari). Uniqbu Journal of Social Sciences, 1(3), 176-183.

Tuasalamony, K., Hatuwe, R. S. M., Susiati, S., Masniati, A., \& Marasabessy, R. N. (2020). PENGEMBANGAN PENDIDIKAN KARAKTER DI SEKOLAH DASAR NEGERI 5 NAMLEA. Pedagogy, 7(2), 81-91.

Hatuwe, Rahma Satya Masna., Tuasalamony, Kurniati., Susiati, Susiati, Masniati, Andi., dan Yusuf, Salma. (2021). MODERNISASI TERHADAP PERUBAHAN SOSIAL MASYARAKAT DESA NAMLEA KABUPATEN BURU. Nusantara: Jurnal Ilmu Pengetahuan Sosial, 8(1), 84-96 
Q-Anees Bambang dan Hambali Adang.2009.Pendidikan Karakter Berbasis alQuran. Bandung:Simbiosa Rekatama Media

Roqib. Moh.2009. Ilmu Pendidikan Islam. Yogyakarta:LkiSYogyakarta

Said al-Khim Mustofa, dkk.2012.Imam Nawawi (Syarah \& Terjemahan Riyadhus Shalihin, Jilid 1).Jakarta:Al-I'tishom

Setiawan Ebta.2012.Kamus Besar Bahasa Indonesia (KBBI) Ofline Versi 1.4 dengan mengacu pada data dari KBBI Daring (edisi III)

Supriyadi Dedi.2010.Pengantar Filsafat Islam (lanjutan) Teori dan Praktik.Bandung:CV PUSTAKA SETIA

Syarbin Amirulloh.2012.Buku Pintar Pendidikan Karakter.Jakarta:as@-prima pustaka

Marzuki,tth.Pendidikan Al-Quran Dan Dasar-Dasar Pendidikan Karakter Dalam Islam, dalam http:// staff.uny.ac.id/sites/default/files/pengabdian/dr-marzukimag/dr-marzuki-mag-pendidikan-al-quran-dan-dasar-dasar-pendidikankarakter-dalam-Islam.pdf (diakses, 20 Maret 2013, pkl. 11.43)

Marzuki,tth. Prinsip Dasar Pendidikan Karakter Perspektif Islam, dalam http://staff.uny.ac.id/sites/default/ files/pengabdian/dr-marzukimag/dr-marzuki-mag-prinsip-dasar-pendidikan-karakter-perspektif-

Islam.pdf (diakses, 20 Maret 2013, pkl. 11.24)

Susiati, S. (2020). The Concept Of Togetherness In The Films" Aisyah Biarkan Kami Bersaudara" By Herwin Novianto.

Susiati, S. (2020). Eksistensi Manusia Dalam Film" Aisyah Biarkan Kami Bersaudara" Karya Herwin Novianto. 